\begin{tabular}{|l|l|l|}
\hline \multicolumn{2}{|c|}{ PublisherInfo } \\
\hline \hline PublisherName & $:$ & BioMed Central \\
\hline \hline PublisherLocation & $:$ & London \\
\hline \hline PublisherImprintName & $:$ & BioMed Central \\
\hline \hline
\end{tabular}

\title{
Mediator of damage checkpoint
}

\begin{tabular}{|l|l|l||}
\hline \multicolumn{2}{|c|}{ ArticleInfo } \\
\hline \hline ArticleID & $:$ & 4711 \\
\hline \hline ArticleDOI & $:$ & $10.1186 /$ gb-spotlight-20030303-01 \\
\hline \hline ArticleCitationID & $:$ & spotlight-20030303-01 \\
\hline \hline ArticleSequenceNumber & $:$ & 63 \\
\hline \hline ArticleCategory & $:$ & Research news \\
\hline ArticleFirstPage & $:$ & 1 \\
\hline \hline ArticleLastPage & $:$ & 2 \\
\hline \hline & & RegistrationDate : 2003-3-3 \\
\hline ArticleHistory & $:$ & OnlineDate \\
\hline \hline ArticleCopyright & $:$ & BioMed Central Ltd2003-3 \\
\hline \hline ArticleGrants & $:$ & \\
\hline \hline ArticleContext & $:$ & 130594411 \\
\hline \hline
\end{tabular}




\section{Jonathan B Weitzman}

Email: jonathanweitzman@hotmail.com

The cell is equipped with a number of critical checkpoint proteins that ensure the integrity of the genome and the coordination of DNA-repair and cell-cycle pathways. In the February 27 Nature three papers describe the role of the MDC1 protein (mediator of DNA damage checkpoint protein 1) in the DNA-damage response. Goldberg et al. found the MDC1 protein during an immunoaffinity purification of the MRE11 repair complex (Nature 2003, 421:952-956). Lou et al. (Nature 2003, 421:957-961) and Stewart et al. (Nature 2003, 421:961-966) identified MDC1 by searching for motifs commonly found in DNA-repair proteins.

MDC1 is a large protein with two carboxy-terminal BRCT (BRCA1 carboxy-terminal) repeats and an amino-terminal phospho-binding motif called FHA (forkhead-associated domain). The MDC1 protein becomes hyperphosphorylated when the cell is hit with ionizing radiation and rapidly localizes to nuclear foci that contain other repair proteins such as CHK2, p53BP1, H2AX and the MRE11 complex. RNA interference experiments demonstrated that cells lacking MDC1 are sensitive to ionizing radiation, exhibit a defective S-phase and G2/M-phase cell-cycle checkpoints after DNA damage, fail to form radiation-induced MRE11 foci and show reduced apoptosis.

These three papers make a convincing case for a central role for MDC1 in the transduction of the DNA-damage signal and the regulation of cell-cycle checkpoints in the DNA-repair pathways.

\section{References}

1. The DNA damage response: putting checkpoints in perspective.

2. Nature, [http://www.nature.com]

3. The Mre11 complex: at the crossroads of DNA repair and checkpoint signalling. 